Article

\title{
AAU-Specific RNA Cleavage Mediated by MazF Toxin Endoribonuclease Conserved in Nitrosomonas europaea
}

\author{
Tatsuki Miyamoto ${ }^{1,2}$, Akiko Yokota ${ }^{2}$, Satoshi Tsuneda ${ }^{1, *}$ and Naohiro Noda ${ }^{1,2, *}$ \\ 1 Department of Life Science and Medical Bioscience, Waseda University, Shinjuku-ku, Tokyo 162-8480, Japan; \\ tatuki-miyamoto@asagi.waseda.jp \\ 2 Biomedical Research Institute, National Institute of Advanced Industrial Science and Technology (AIST), \\ Tsukuba, Ibaraki 305-8566, Japan; akiko-yokota@aist.go.jp \\ * $\quad$ Correspondence: stsuneda@waseda.jp (S.T.); noda-naohiro@aist.go.jp (N.N.); Tel.: +81-3-5369-7325 (S.T.); \\ +81-29-861-6489 (N.N.)
}

Academic Editor: Anton Meinhart

Received: 22 March 2016; Accepted: 30 May 2016; Published: 4 June 2016

\begin{abstract}
Nitrosomonas europaea carries numerous toxin-antitoxin systems. However, despite the abundant representation in its chromosome, studies have not surveyed the underlying molecular functions in detail, and their biological roles remain enigmatic. In the present study, we found that a chromosomally-encoded MazF family member, predicted at the locus NE1181, is a functional toxin endoribonuclease, and constitutes a toxin-antitoxin system, together with its cognate antitoxin, MazE. Massive parallel sequencing provided strong evidence that this toxin endoribonuclease exhibits RNA cleavage activity, primarily against the AAU triplet. This sequence-specificity was supported by the results of fluorometric assays. Our results indicate that N. europaea alters the translation profile and regulates its growth using the MazF family of endoribonuclease under certain stressful conditions.
\end{abstract}

Keywords: Nitrosomonas europaea; toxin-antitoxin system; MazF; sequence-specific endoribonuclease

\section{Introduction}

Nitrosomonas europaea is a chemolithoautotrophic bacterium in the beta-subdivision of Proteobacteria [1]. It inhabits aquatic and terrestrial environments and acquires reductants by oxidizing ammonia to nitrite [2]. Since ammonia oxidization is a key reaction in both the ecological nitrogen cycle and environmental engineering [3], the physiological responses of $N$. europaea in a variety of environments have been investigated; it is now widely accepted that this bacterium responds sensitively to environmental changes such as temperature, ammonia concentration, $\mathrm{pH}$, nitrite concentration, inorganic substances, and organic compounds [4-8].

The genome information of this bacterium was previously published [9]. Interestingly, N. europaea bears a large number of putative toxin-antitoxin (TA) systems, which are stress-responsible genetic modules widespread in bacterial and archaeal lineages. This indicates that N. europaea acclimates to variable environments using these systems [10]. However, no studies have surveyed the molecular functions of these TA systems conserved in this chemolithoautotroph.

TA systems are typically encoded by a set of two genes: one for a long-lived toxin that inhibits vital processes in microbial cells and the other for a short-lived antitoxin that neutralizes toxin activity [11]. In most cases, antitoxins are preferentially degraded under stressful conditions. This results in toxin liberation and subsequent growth arrest [11]. Although the cellular targets of toxins are diverse, most previously identified toxins are known to arrest microbial growth by cleaving intracellular RNAs [12].

Escherichia coli MazF, which belongs to the MazEF family with its cognate antitoxin MazE, is one of the best-characterized toxins [13]. Under stressful environments, MazF specifically cleaves 
cellular RNAs at ACA sites irrespective of the ribosome [14], serving as a post-transcriptional regulator [15,16]. Interestingly, MazF homologues are well-conserved in the prokaryotic domain [10,17]. Additionally, they cleave discrete RNA sites based on recognition length and sequences [14,18-28]. Therefore, MazF homologues are thought to play diverse biological roles; indeed, they have been implicated in programmed cell death [29], dormancy [30], phage abortive infection [31,32], and pathogenicity $[21,22,33]$.

In the present study, we showed a MazF homologue, predicted at NE1181 in the N. europaea chromosome $\left(\mathrm{MazF}_{\mathrm{NE1181}}\right)$, is a toxin endoribonuclease, which forms a TA pair together with its cognate antitoxin MazE, encoded by the NE1182 locus (MazE $E_{N E 1182}$ ). Using a combination of RNA-seq and fluorometric assays, this enzyme was found to cleave AAU sites in a sequence-specific manner. These results indicate that $N$. europaea translation is altered by the action of this enzyme during specific environmental stresses.

\section{Results}

\subsection{Enzymatic Activity of MazF $F_{N E 1181}$}

MazF $_{\mathrm{NE} 1181}$ codes for a 113 -residue protein and shows $26.9 \%$ identity to $E$. coli MazF (MazFec) (Figure 1A), but its function remains unclear. We purified histidine-tagged MazF $F_{\text {NE1181 }}$ (Figure 1B) and then examined its endoribonuclease activity. We incubated a 533-nt RNA with this enzyme, and observed RNA degradation (Figure 1C, Lane 3), which suggests that MazF $F_{\text {NE1181 is a toxin }}$ endoribonuclease. Next, in order to rule out the potential contamination with RNases, a cognate MazE antitoxin (MazE $\mathrm{NE1182}$ ) was purified (Figure 1B). The addition of MazE $\mathrm{NE1182}_{2}$ was shown to block RNA cleavage (Figure 1C, Lanes 4-6), demonstrating that it is specifically mediated by MazF $F_{\text {NE1181. }}$. Moreover, the cleavage patterns differed between MazFec- and MazF ${ }_{\text {NE1181 }}$-treated RNAs (Figure 1D). Taken together with the fact that both MazF proteins yielded numerous RNA fragments, it appears that $\mathrm{MazF}_{\mathrm{NE} 1181}$ recognizes short unique sequences.

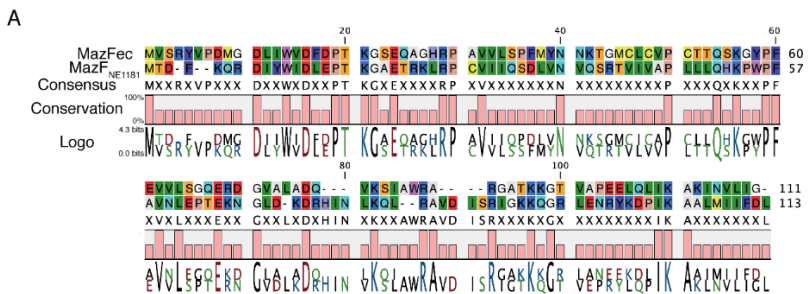

C

D
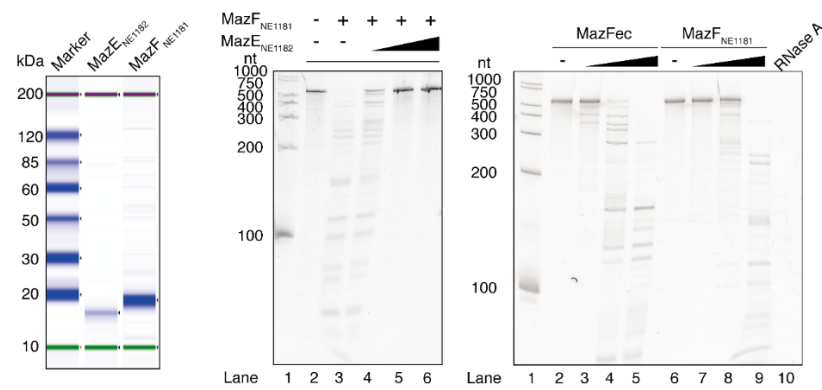

Figure 1. A MazF homologue isolated from N. europaea. (A) Pairwise alignment of two MazF sequences; (B) molecular weight and purity of MazEF pair; (C) enzymatic activity of MazE $\mathrm{NE1182}_{2}$ and MazF $\mathrm{NE}_{\mathrm{N} 181}$.

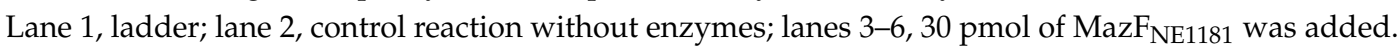
For lanes 4-6, 20, 60, and 180 pmol of MazE $\mathrm{NE1182}_{2}$ was added, respectively; and (D) cleavage pattern of

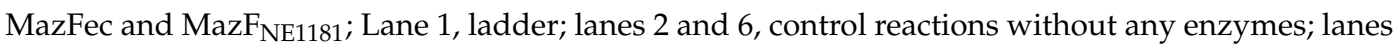
3-5, 10, 50, and $250 \mathrm{ng}$ of MazFec was added, respectively; lanes 7-9, 10, 50, and $250 \mathrm{ng}$ of MazF $\mathrm{NE}_{1181}$ was added, respectively; lane 10, $100 \mathrm{ng}$ of RNase A was added as a control. 


\subsection{Cleavage Sequence Identification Using Massive Parallel Sequencing}

We recently developed an RNA-seq-based approach for cleavage sequence determination [25]. Hence, we attempted to define the cleavage specificity of MazF $\mathrm{NE1181}_{1}$ using this approach (see Appendix A). When analyzing the MazF $\mathrm{N}_{\mathrm{NE} 1181}$-cleaved RNA sites, we found that the AAT triplet was highly conserved (Figure $2 \mathrm{~B}$ ), suggesting that $\mathrm{MazF}_{\mathrm{NE} 1181}$ preferably recognizes and cuts RNAs at the unique triplet AAU. Furthermore, since the coverage significantly increased at the second A-residue (Table $\mathrm{S} 1$ and Figure 2B), MazF $\mathrm{NE1181}_{1}$ likely cleaves RNAs between the first and second adenines.

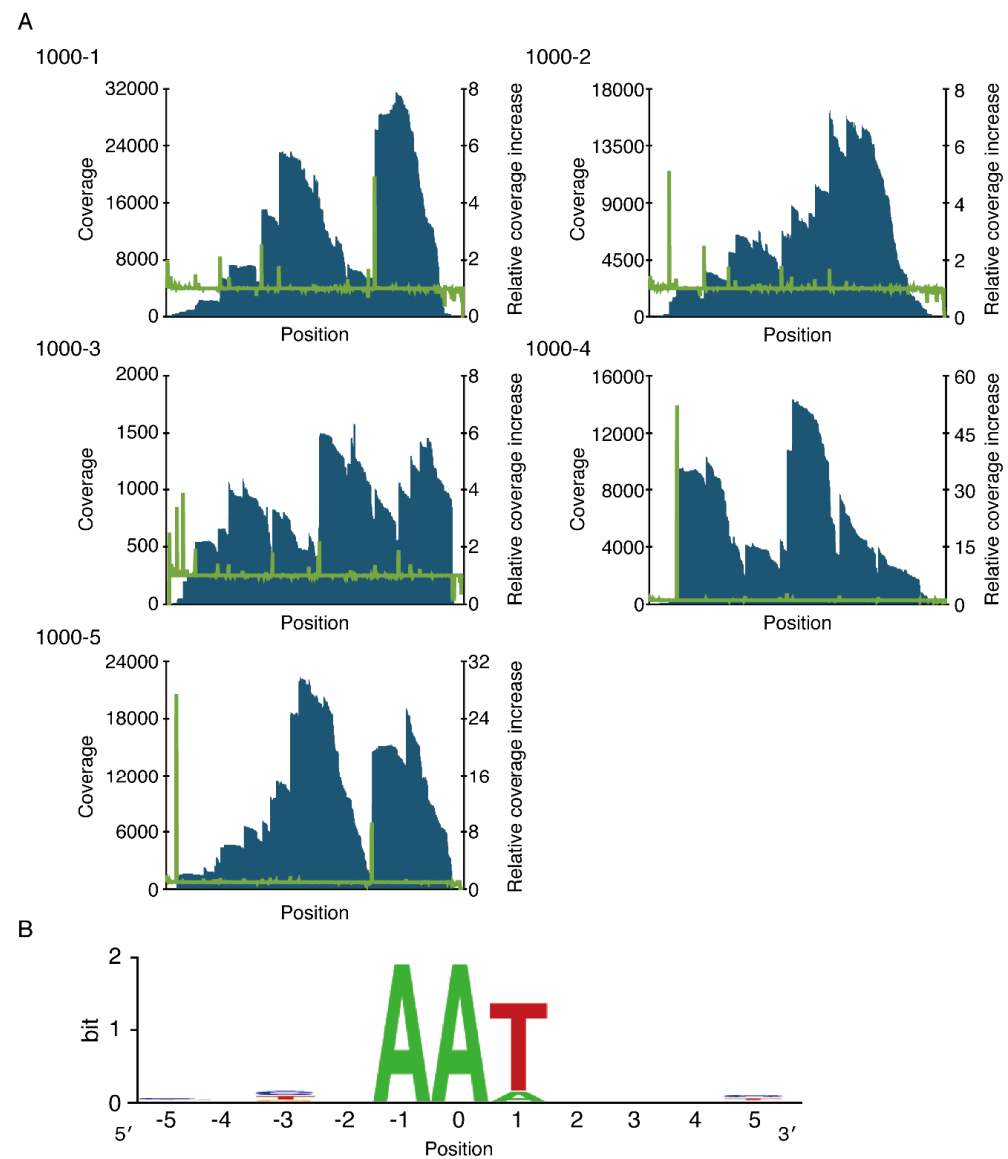

Figure 2. Analysis of the cleavage sequence of $\mathrm{MazF}_{\mathrm{NE1181}}$. (A) Graph of the coverage (blue bar) and relative coverage increase (green line); and (B) conserved sequence around nucleotide positions with increased coverage. Nucleotide position with significant increases in coverage was set to zero.

\subsection{Cleavage-Specificity Validation Based on Fluorescence Resonance Energy Transfer}

To further confirm its sequence-specificity, we next examined whether MazF $\mathrm{FE1181}_{\text {cleaves }}$ fluorescent-modified oligonucleotides (Table 1) based on fluorescence resonance energy transfer (see Appendix B) [25,34].

In agreement with the results obtained from RNA-seq, when a chimeric DNA/RNA oligonucleotide DR-13-AAU was first treated with $\mathrm{MazF}_{\mathrm{NE1181}}$, fluorescent intensity rapidly increased (Figure 3A), verifying that AAU is the target of this enzyme. Therefore, we next examined whether AAA was also susceptible to this enzyme, since this triplet was detected by massive parallel sequencing (Figure 2B, Table S1). We synthesized DR-13-AAA and incubated it with MazF $\mathrm{NE1181}_{1}$. As expected, the AAA triplet was also cleaved, but the cleavage activity was greatly weakened (Figure 3B); indeed, while DR-13-AAU was completely cleaved within 15 min, nearly $50 \%$ of DR-13-AAA remained intact, even at the end of the reaction. Thus, AAU was considered to be the main target of the enzyme. 
Table 1. Fluorescent-modified oligonucleotides used in fluorometric assay.

\begin{tabular}{cc}
\hline Name & Sequence $\left(5^{\prime} \text { to } \mathbf{3}^{\prime}\right)^{\mathbf{a}}$ \\
\hline DR-13-AAU & AAAAAAAUAAAAA \\
DR-13-AAA & AAAAAAAAAAAAA \\
D-13-AAA & AAAAAAAAAAAAA \\
R-13-GUUGU & GUUGUCAUGCCGG \\
R-13-UCUCG & UCUCGGUGCGUUG \\
R-13-UGACA & UGACACGAACCGC \\
DR-13-GAU & AAAAAGAUAAAAA \\
DR-13-AAC & AAAAA AAAAAAAA \\
\hline
\end{tabular}

a Underlined letters represent RNA nucleotides and the other letters represent DNA nucleotides.

(A) DR-13-AAU
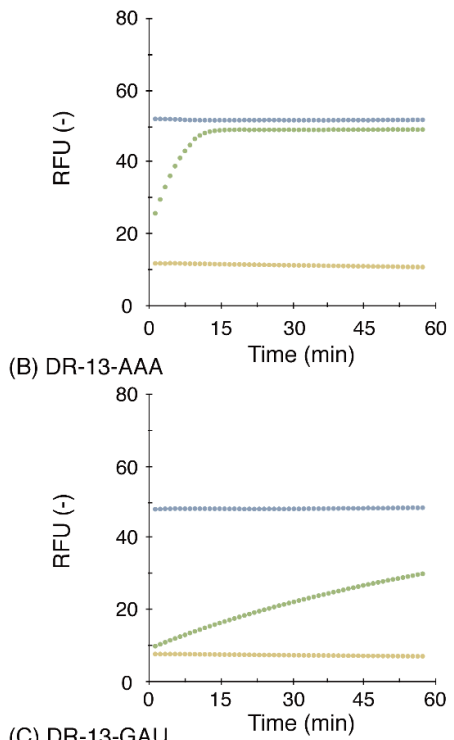

(C) DR-13-GAU

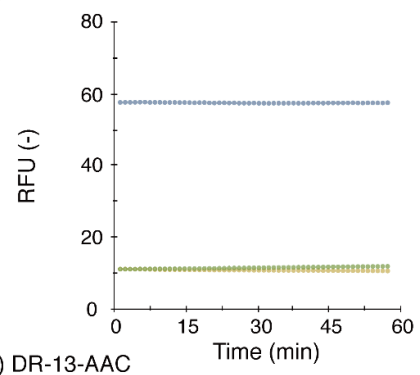

(D) DR-13-AAC

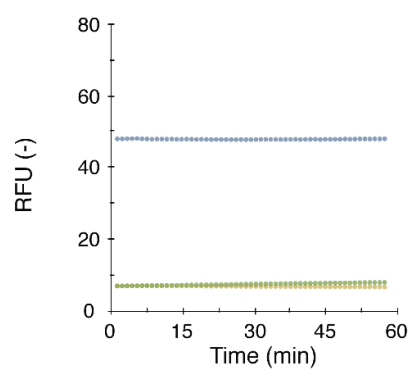

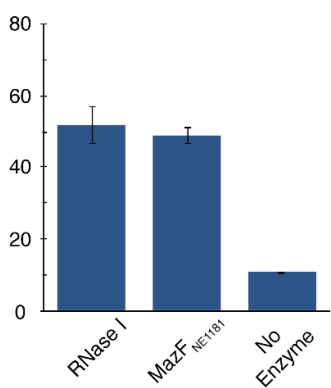
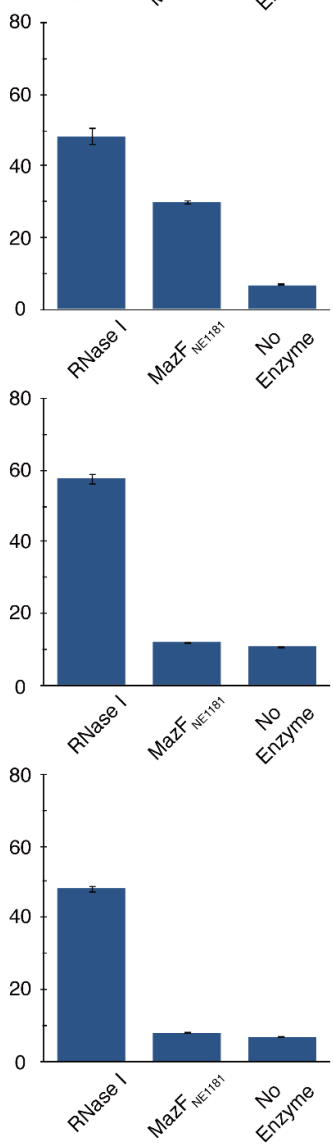

Figure 3. MazF $\mathrm{F}_{\mathrm{NE} 1181}$-mediated sequence-specific RNA cleavage. Two hundred nanograms of

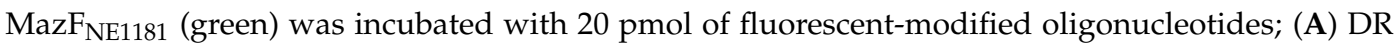
13-AAU; (B) DR-13-AAA; (C) DR-13-GAU; and (D) DR-13-AAC. In the control reactions, fluorescent intensities in the presence of $1 \mathrm{U}$ of RNase I (blue) and in the absence of enzymes (yellow) at each time point (left) and end point (right) were measured. 
Notably, a DNA oligonucleotide that is composed of a DNA adenine repeat (D-13-AAA) was

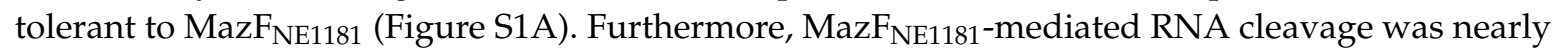
completely blocked for three RNA oligonucleotides (R-13-GUUGU, R-13-UCUCG, and R-13-UGACA) (Figures S1B-D), the sequences of which were derived from substrate RNA used in the RNA-seq but did not include the AAU and AAA sequences. Taking these results together with the results showing that DR-13-AAU cleavage was counteracted by the addition of MazE $\mathrm{NE1182}_{2}$ in a dose-dependent manner (Figure S2), the possibility of contamination by DNases and RNases was, again, excluded.

Finally, we prepared two additional fluorogenic oligonucleotides (DR-13-GAU and DR-13-AAC) to investigate whether MazF $\mathrm{NE1181}_{\mathrm{N} 1}$ strictly recognizes specific sequences. As anticipated, neither DR-13-GAU, an oligonucleotide whose first RNA base A is substituted with another purine base G, nor DR-13-AAC, whose last RNA base $\mathrm{U}$ is substituted with another pyrimidine base $\mathrm{C}$, were cleaved, demonstrating the strictness of $\mathrm{MazF}_{\mathrm{NE1181}}$-recognition (Figure 3C,D). Thus, MazF $\mathrm{NE1181}_{1}$ is a canonical toxin endoribonuclease that mainly targets the AAU sequence.

\section{Discussion}

TA systems are ubiquitous elements encoded in prokaryotic plasmids and chromosomes [10,35-37] and are involved in stress adaptation by modulating bacterial and archaeal growth. Although toxin molecules regulate microbial growth through a variety of mechanisms, an enormous number of toxins are known to function as RNA endoribonucleases. Based on the mode of action, these toxin endoribonucleases are classified into two categories: (i) ribosome-dependent endoribonucleases (i.e., RelE, YafQ, and HigB) [38-40] and (ii) ribosome-independent endoribonucleases (i.e., MazF, HicA, and $\mathrm{VapC})[14,41,42]$.

In the current study, we demonstrated that the AAU site is the prime target of N. europara MazF $\left(\mathrm{MazF}_{\mathrm{NE1181}}\right)$ (Figures 2 and 3). The consensus sequence for the MazF $\mathrm{F}_{\mathrm{NE} 1181}$ was previously known as $5^{\prime}$-GAAU-3' and $5^{\prime}$-AAAU-3' [43]. However, these cleavage sequences were roughly estimated based on gel electrophoresis results. Using a combination of massive parallel sequencing and fluorometric assays, we refined the cleavage-specificity of $\mathrm{MazF}_{\mathrm{NE1181}}$.

It has been well-established that transcripts without recognition sequences are tolerant to toxin endoribonucleases $[21,22,44]$. Accordingly, we extracted protein-coding sequences without any AAU triplets. We found that eight out of 2462 sequences were devoid of this triplet (Table 2).

Table 2. Protein coding sequences without AAU sequences.

\begin{tabular}{cccc}
\hline Locus & Gene Symbol & Length $\mathbf{( b p )}$ & Product Name \\
\hline NE0390 & rpmH & 135 & LSU Ribosomal protein L34 \\
NE2575 & merE & 237 & mercury resistance protein \\
NE0841 & merP & 276 & mercury scavenger protein \\
NE0842 & merT & 351 & mercuric transport protein \\
NE1224 & - & 264 & hypothetical protein \\
NE1344 & - & 279 & hypothetical protein \\
NE2523 & - & 231 & hypothetical protein \\
NE2538 & - & 912 & hypothetical protein \\
\hline
\end{tabular}

Interestingly, three of eight genes were identified within mer operons (Table 2), which are composed of merTPCADE and merR (Table S2) [6,7]. Previously, these genes were inferred to be helpful for improving the resistance to mercury [6]. Furthermore, they were implicated in the resistance of N. europaea to other heavy metal stresses; in fact, these genes were significantly upregulated after heavy metal exposure [6,7]. Considering that some toxin endoribonucleases regulate gene expression by differentially destabilizing mRNAs, including recognition sequences [45], MazF $\mathrm{F}_{\mathrm{NE1181}}$ may function as a post-transcriptional regulator and improve heavy metal resistance by enriching the transcripts within this operon; indeed, mazEF expression at this locus was reported to be upregulated under zinc stress [7]. 
Additionally, the gene sequence in the locus NE1224 did not include AAU triplets (Table 2). RASTA-Bacteria, an automated web-based tool for identifying prokaryotic toxin-antitoxin systems [46], predicted that this gene codes for an antitoxin that comprises a TA system along with a VapC family of toxin endoribonucleases (NE1225) [35,46]. Given that protein antitoxins typically suppress the expression of the TA system by binding its promoter [47], this putative antitoxin (NE1224) may repress the expression of VapC toxin endoribonuclease, in which case N. europaea may utilize these endoribonucleases depending on their surroundings and acclimate to the environments by using RNAs that evade MazF $\mathrm{FE}_{\mathrm{N} 181}$ or VapC-catalyzed cleavage.

In conclusion, we found that MazF $\mathrm{NE}_{\mathrm{NE} 181}$ is a functional enzyme and possesses endoribonuclease activity. In addition, this MazF homologue mainly recognizes and cleaves RNAs at AAU sites in a ribosome-independent manner. This indicates that N. europaea alters its translation and copes with certain stresses with the aid of this enzyme.

\section{Materials and Methods}

\subsection{Plasmids and Oligonucleotides}

The pET21c expression vector was purchased from Takara Bio Service (Shiga, Japan). pET19b expression vector encoding maz $E_{\mathrm{NE} 1182}$, with the codon usage optimized for recombinant protein expression in E. coli, was purchased from GenScript Japan (Tokyo, Japan). pMK-T encoding maz $F_{\mathrm{NE} 1181}$, whose codon usage was optimized for recombinant protein expression in E. coli, was purchased from Life Technologies Japan Ltd. (Tokyo, Japan). Fluorescent-modified oligonucleotides were purchased from Japan Bio Services (Saitama, Japan).

\subsection{Plasmid Construction}

pMK-T encoding $m a z F_{\text {NE1181 }}$ and pET21c were digested with XhoI and BamHI (Toyobo, Osaka, Japan). These linearized DNA fragments were cleaned using a MinElute PCR purification kit (Qiagen, Hilden, Germany). The $m a z F_{N E 1181}$ fragment was then cloned into the multiple cloning sites of pET21c

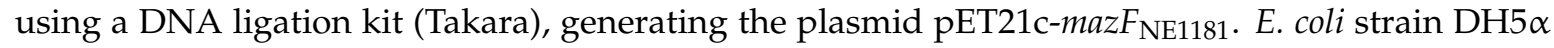
(Nippon Gene, Tokyo, Japan) was transformed with pET21c-maz $F_{\mathrm{NE1181}}$, and this transformant was grown at $37^{\circ} \mathrm{C}$ on LB plate containing $100 \mu \mathrm{g} / \mathrm{mL}$ ampicillin. pET21c-maz $F_{\mathrm{NE1181}}$ was extracted using the QIAprep Spin Miniprep Kit (Qiagen), and the sequence was confirmed using an AB 3500 Genetic Analyzer (Applied Biosystems, Foster City, CA, USA) according to the manufacturer's protocol.

\subsection{Expression of $M a z E_{N E 1182}$}

E. coli strain BL21 (DE3) cells (BioDynamics Laboratory Inc., Tokyo, Japan) were transformed using $\mathrm{pET19b}-m a z \mathrm{E}_{\mathrm{NE} 1182}$. These cells were pre-cultivated overnight in LB medium supplemented with $100 \mu \mathrm{g} / \mathrm{mL}$ ampicillin at $37^{\circ} \mathrm{C}$. Afterward, they were inoculated into $1 \mathrm{~L}$ of LB medium containing $100 \mu \mathrm{g} / \mathrm{mL}$ ampicillin. MazE $\mathrm{NE}_{\mathrm{NE} 1182}$ was induced by the addition of $1 \mathrm{mM}$ isopropyl $\beta$-D-1-thiogalactopyranoside, when OD600 reached approximately 1.0. After $3.5 \mathrm{~h}$ of incubation, the cells were harvested by centrifugation at $7000 \mathrm{~g}$, and stored at $-80^{\circ} \mathrm{C}$ until further use.

\subsection{Purification of $M a z E_{N E 1182}$}

Recombinant MazE $\mathrm{NE1182}_{2}$ was purified as described previously with minor modifications [25]. E. coli cells containing MazE $\mathrm{E}_{\mathrm{NE} 1182}$ were thawed on ice and resuspended in $14 \mathrm{~mL}$ of binding buffer (20 mM sodium phosphate ( $\mathrm{pH} 8.0$ ), $300 \mathrm{mM} \mathrm{NaCl}, 40 \mathrm{mM}$ imidazole, and $5 \mathrm{mM}$ 2-mercaptoethanol). Afterward, these cells were incubated on ice for $5 \mathrm{~min}$ in the presence of $0.2 \mathrm{mg} / \mathrm{mL}$ lysozyme. The cells were lysed by sonication and collected by centrifugation at $7000 \mathrm{~g}$ for $15 \mathrm{~min}$. Afterward, the supernatant was filtered through a $0.45-\mu \mathrm{m}$ membrane (Millex, Darmstadt, Germany). After equilibrating a 1-mL His-Trap FF column (GE Healthcare, Little Chalfont, UK), the supernatant was applied to the column and washed with 32 column volumes of binding buffer using AKTA pure 25 
(GE Healthcare). Deca-histidine tagged MazE $\mathrm{NE1182}_{2}$ was selectively eluted with the elution buffer using following program: flow rate, $1 \mathrm{~mL} / \mathrm{min}$; linear elution gradient, 20 column volumes; fraction size, $0.5 \mathrm{~mL}$. The following composition of the elution buffer was used: $20 \mathrm{mM}$ sodium phosphate (pH 8.0), $300 \mathrm{mM} \mathrm{NaCl}, 500 \mathrm{mM}$ imidazole, and $5 \mathrm{mM}$ 2-mercaptoethanol. The 38th fraction from the beginning of the elution program was used for further experiments. The molecular weight and purity were confirmed using the Agilent 2200 TapeStation P200 ScreenTape Assay (Agilent Technologies, Santa Clara, CA, USA). Protein concentration was determined using the Qubit Protein Assay Kit (Life Technologies, Carlsbad CA, USA).

\subsection{Expression of $M a z F_{N E 1181}$}

E. coli strain BL21 (DE3) (Nippon Gene) was transformed with pET21c-maz $F_{\mathrm{NE} 1181}$ via heat shock, and this transformant was pre-cultivated overnight in LB medium supplemented with $100 \mu \mathrm{g} / \mathrm{mL}$ ampicillin at $37^{\circ} \mathrm{C}$. Pre-cultivated E. coli cells were then inoculated into $1 \mathrm{~L}$ LB medium containing

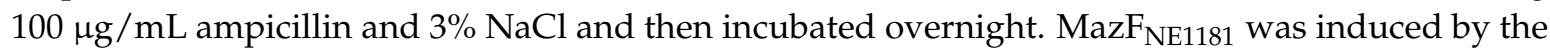
addition of $1 \mathrm{mM}$ isopropyl $\beta$-D-1-thiogalactopyranoside. After $3.5 \mathrm{~h}$ of incubation, the cells were harvested by centrifugation at $7000 \mathrm{~g}$ and then stored at $-80^{\circ} \mathrm{C}$ until use.

\subsection{Purification of MazF $F_{N E 1181}$}

Recombinant $\mathrm{MazF}_{\mathrm{NE1181}}$ was purified as described previously with minor modifications [25]. E. coli cells containing $\mathrm{MazF}_{\mathrm{NE} 1181}$ were thawed on ice and resuspended in $15 \mathrm{~mL}$ of binding buffer (20 mM sodium phosphate ( $\mathrm{pH} 8.0$ ), 0.05\% Triton X-100, $300 \mathrm{mM} \mathrm{NaCl}, 40 \mathrm{mM}$ imidazole, and $5 \mathrm{mM}$ 2-mercaptoethanol). Suspended cells were then incubated on ice for $5 \mathrm{~min}$ in the presence of $0.2 \mathrm{mg} / \mathrm{mL}$ lysozyme. The cells were lysed by sonication and collected by centrifuging at $7000 \mathrm{~g}$ for $15 \mathrm{~min}$. The supernatant was then filtered through a $0.45-\mu \mathrm{m}$ membrane (Millex). After equilibrating a $1-\mathrm{mL}$ His-Trap FF crude column (GE Healthcare), the supernatant was applied to the column and washed with 32 column volumes of binding buffer using AKTA pure 25 (GE Healthcare). Hexa-histidine tagged $\mathrm{MazF}_{\mathrm{NE} 1181}$ was selectively eluted, using the elution buffer, with following program: flow rate, $1 \mathrm{~mL} / \mathrm{min}$; linear elution gradient, 20 column volumes; fraction size, $0.5 \mathrm{~mL}$. The elution buffer contained $20 \mathrm{mM}$ sodium phosphate ( $\mathrm{pH}$ 8.0), 0.05\% Triton X-100, $300 \mathrm{mM} \mathrm{NaCl,} 500 \mathrm{mM}$ imidazole, and $5 \mathrm{mM}$ 2-mercaptoethanol. The 22th fraction from the beginning of the elution program was used for further experiments. The molecular weight and purity were confirmed using the Agilent 2200 TapeStation P200 ScreenTape Assay (Agilent Technologies). Protein concentration was determined using the Qubit Protein Assay Kit (Life Technologies).

\subsection{Enzymatic Activity of MazF $F_{N E 1181}$ and MazE $E_{N E 1182}$}

Synthetic RNA constructs were prepared as described in our previous study [25]. Thirty picomoles of $\mathrm{MazF}_{\mathrm{NE} 1181}$ were pre-incubated with 20,60, or $180 \mathrm{pmol}$ of MazE $\mathrm{NE1182}_{2}$ at room temperature for $10 \mathrm{~min}$. Following this, $100 \mathrm{ng}$ of RNA 500-2 was added and the mixture was incubated at $37^{\circ} \mathrm{C}$ for $30 \mathrm{~min}$ in MazF reaction buffer (20 mM Tris- $\mathrm{HCl}$ (pH 8.0), $1 \mathrm{mM}$ dithiothreitol, 0.01\% Triton X-100, and $4 \mathrm{U}$ of recombinant RNase inhibitor (Takara)) in a final volume of $50 \mu \mathrm{L}$. Samples were purified by RNA Clean and Concentrator ${ }^{\mathrm{TM}}-5$ (Zymo Research, Orange, CA, USA) and the gel loading buffer II (Ambion, Austin, TX, USA) was added to each sample. They were incubated at $95^{\circ} \mathrm{C}$ for $5 \mathrm{~min}$ and separated on a $10 \%$ polyacrylamide gel containing $7 \mathrm{M}$ urea. RNA was stained using SYBR Gold (Life Technologies) and detected using a Typhoon 9210 imager (GE Healthcare).

\subsection{Endoribonuclease Activity of MazF $F_{N E 1181}$}

Synthetic RNA constructs were prepared as described in our previous study [25]. RNA 500-2 was incubated with 10,50, or $250 \mathrm{ng}$ of MazFec or MazF $\mathrm{NE}_{1181}$ at $37^{\circ} \mathrm{C}$ for $30 \mathrm{~min}$ in MazF reaction buffer in $25-\mu \mathrm{L}$ reaction volume. Gel loading buffer II (Ambion) was added to each sample. These samples were incubated at $95{ }^{\circ} \mathrm{C}$ for $5 \mathrm{~min}$ and then separated on a $10 \%$ polyacrylamide gel containing $7 \mathrm{M}$ 
urea. RNA was stained using SYBR Gold (Life Technologies) and then detected using a Typhoon 9210 imager (GE Healthcare).

\subsection{Cleavage Sequence Identification}

The cleavage sequence was identified using the protocols described in our previous study [25]. First, $1.5 \mu \mathrm{g}$ of five RNA mixtures were incubated with $400 \mathrm{ng}$ of $\mathrm{MazF}_{\mathrm{NE1181}}$ at $37^{\circ} \mathrm{C}$ for $30 \mathrm{~min}$ in MazF reaction buffer. Phosphorylation, barcode ligation, and sequencing library construction were performed as described by Miyamoto et al. [25]. Sequencing was performed using the MiSeq platform with the MiSeq 500 cycles reagent kit v2 (Illumina, San Diego, CA, USA) according to the manufacturer's protocol. Sequence data was analyzed using CLC Genomics 7.5.1. The parameters described by Miyamoto et al. [25] were used for the analysis, and 25 sequences were analyzed using WebLogo [48]. The deep sequencing dataset was deposited into the DDBJ Sequence Read Archive (DRA004562).

\subsection{Fluorometric Detection of Maz $F_{N E 1181}$ Activity}

The flurometric assay was performed as described previously [25]. Two hundred nanograms of $\mathrm{MazF}_{\mathrm{NE} 1181}$ or $1 \mathrm{U}$ of RNase I (Epicentre Biotechnologies, Madison, WI, USA) were incubated with 20 pmol of fluorescent-labeled oligonucleotides in MazF reaction buffer in a total volume of $20 \mu \mathrm{L}$. All reactions were conducted at $37^{\circ} \mathrm{C}$ in triplicate and fluorescent intensity was recorded every 1 min using a Light Cycler 480 system (Roche, Basel, Switzerland) with $483 \mathrm{~nm}$ excitation and $533 \mathrm{~nm}$ detection filters.

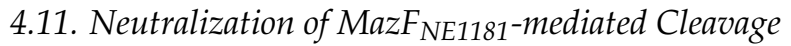

Ten picomoles of MazF $\mathrm{NE}_{\mathrm{N} 181}$ were pre-incubated with 2, 10, or 50 pmol of MazE $\mathrm{E}_{\mathrm{NE} 1182}$ at room temperature for $10 \mathrm{~min}$. Afterward, $20 \mathrm{pmol}$ of fluorescent-labeled oligonucleotide (DR-13-AAU) was added, and the mixture was incubated at $37^{\circ} \mathrm{C}$ in MazF reaction buffer in a final volume of $20 \mu \mathrm{L}$. All reactions were conducted at $37^{\circ} \mathrm{C}$ in triplicate and fluorescent intensity was recorded every $1 \mathrm{~min}$ using a Light Cycler 480 system (Roche) with $483 \mathrm{~nm}$ excitation and $533 \mathrm{~nm}$ detection filters. In the control reactions, fluorescent intensities in the presence of $1 \mathrm{U}$ of RNase I (Epicentre) and in the absence of enzymes were measured.

\subsection{Accession Numbers}

The GenBank accession numbers are as follows: $m a z E_{N E 1182}$ protein sequence (WP_011111771), $m a z F_{N E 1181}$ protein sequence (WP_011111770) and artificially designed RNAs; 500-2 (AB610940), 1000-1 (AB610944), 1000-2 (AB610945), 1000-3 (AB610946), 1000-4 (AB610947), and 1000-5 (AB610948).

Supplementary Materials: The following are available online at www.mdpi.com/2072-6651/8/6/174/s1, Figure S1:

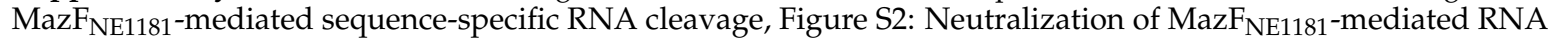
cleavage, Table S1: Twenty-five sequences with MazF $\mathrm{NE}_{\mathrm{N} 181}$ cleavage, Table S2: Genes consisting of mer operon.

Acknowledgments: This work was supported by JSPS KAKENHI Grant Number 15K14241.

Author Contributions: Tatsuki Miyamoto, Akiko Yokota, Satoshi Tsuneda, and Naohiro Noda conceived and designed the experiments; Tatsuki Miyamoto and Akiko Yokota performed the experiments; Tatsuki Miyamoto analyzed the data; and Tatsuki Miyamoto wrote the paper.

Conflicts of Interest: The authors declare no conflict of interest.

\section{Abbreviations}

The following abbreviations are used in this manuscript:

TA

6-FAM

BHQ-1

RASTA-Bacteria toxin-antitoxin

6-carboxyfluorescein

black hole quencher-1

rapid automated scan for toxins and antitoxins in bacteria 


\section{Appendix A}

The five artificially designed RNAs (1000-1, 1000-2, 1000-3, 1000-4, and 1000-5) including 1000-nt diverse sequences were fragmented with $\mathrm{MazF}_{\mathrm{NE1181}}$. These RNAs were sequenced using the Illumina MiSeq platform with slightly modified RNA-seq protocols. The sequencing reads, which contained cleavage sites in their 5 '-ends, were mapped against five reference sequences. Nucleotides showing increases in coverage were consistent with the first base of the cleaved RNAs (Figure 2A). These nucleotides were differentially detected by extracting the positions showing a large relative coverage increase, which is the value defined as the coverage at the $n+1^{\text {th }}$ position divided by the coverage at the $\mathrm{n}^{\text {th }}$ position. Sequences located five bases upstream and five bases downstream of these nucleotides were then extracted (Table S1) as outlined in our previous study [25]. A total of 25 sequences (five sequences derived from five references) were analyzed using WebLogo.

\section{Appendix B}

Fluorogenic oligonucleotides modified with 6-carboxyfluorescein (6-FAM) at the $5^{\prime}$-end and black hole quencher-1 (BHQ-1) at the $3^{\prime}$-end were used in this study. The fluorescence from 6-FAM is typically quenched by BHQ-1, but when oligonucleotides are cleaved, these two dyes are no longer in close proximity and fluorescent intensity increases [25,34].

\section{References}

1. Arp, D.J; Sayavedra-Soto, L.A.; Hommes, N.G. Molecular biology and biochemistry of ammonia oxidation by Nitrosomonas europaea. Arch. Microbiol. 2002, 178, 250-255.

2. Bothe, H.; Jost, G.; Schloter, M.; Ward, B.B.; Witzel, K. Molecular analysis of ammonia oxidation and denitrification in natural environments. FEMS Microbiol. Rev. 2000, 24, 673-690. [CrossRef] [PubMed]

3. Arp, D.J.; Stein, L.Y. Metabolism of inorganic N compounds by ammonia-oxidizing bacteria. Crit. Rev. Biochem. Mol. Biol. 2003, 38, 471-495. [CrossRef] [PubMed]

4. Groeneweg, J.; Sellner, B.; Tappe, W. Ammonia oxidation in Nitrosomonas at $\mathrm{NH}_{3}$ concentrations near km: Effects of $\mathrm{pH}$ and temperature. Water Res. 1994, 28, 2561-2566. [CrossRef]

5. Stein, L.Y.; Arp, D.J. Loss of ammonia monooxygenase activity in Nitrosomonas europaea upon exposure to nitrite. Appl. Environ. Microbiol. 1998, 64, 4098-4102. [PubMed]

6. Park, S.; Ely, R.L. Candidate stress genes of Nitrosomonas europaea for monitoring inhibition of nitrification by heavy metals. Appl. Environ. Microbiol. 2008, 74, 5475-5482. [CrossRef] [PubMed]

7. Park, S.; Ely, R.L. Genome-wide transcriptional responses of Nitrosomonas europaea to zinc. Arch. Microbiol. 2008, 189, 541-548. [CrossRef] [PubMed]

8. Gvakharia, B.O.; Permina, E.A.; Gelfand, M.S.; Bottomley, P.J.; Sayavedra-Soto, L.A.; Arp, D.J. Global transcriptional response of Nitrosomonas europaea to chloroform and chloromethane. Appl. Environ. Microbiol. 2007, 73, 3440-3445. [CrossRef] [PubMed]

9. Chain, P.; Lamerdin, J.; Larimer, F.; Lao, V.; Land, M.; Hauser, L.; Klotz, M.; Norton, J.; Arciero, D.; Hommes, N.; et al. Complete genome sequence of the ammonia-oxidizing bacterium and obligate chemolithoautotroph Nitrosomonas europaea. J. Bacteriol. 2003, 185, 2759-2773. [CrossRef] [PubMed]

10. Pandey, D.P.; Gerdes, K. Toxin-antitoxin loci are highly abundant in free-living but lost from host-associated prokaryotes. Nucleic Acids Res. 2005, 33, 966-976. [CrossRef] [PubMed]

11. Schuster, C.F.; Bertram, R. Toxin-antitoxin systems are ubiquitous and versatile modulators of prokaryotic cell fate. FEMS Microbiol. Lett. 2013, 340, 73-85. [CrossRef] [PubMed]

12. Yamaguchi, Y.; Inouye, M. Regulation of growth and death in Escherichia coli by toxin-antitoxin systems. Nat. Rev. Microbiol. 2011, 9, 779-790. [CrossRef] [PubMed]

13. Aizenman, E.; Engelberg-Kulka, H.; Glaser, G. An Escherichia coli chromosomal "addiction module" regulated by guanosine 3',5'-bispyrophosphate: a model for programmed bacterial cell death. Proc. Natl. Acad. Sci. USA 1996, 93, 6059-6063. [CrossRef] [PubMed]

14. Zhang, Y.; Zhang, J.; Hoeflich, K.P.; Ikura, M.; Qing, G.; Inouye, M. MazF cleaves cellular mRNAs specifically at ACA to block protein synthesis in Escherichia coli. Mol. Cell 2003, 12, 913-923. [CrossRef] 
15. Amitai, S.; Kolodkin-Gal, I.; Hananya-Meltabashi, M.; Sacher, A.; Kulka, H.E. Escherichia coli MazF leads to the simultaneous selective synthesis of both "death proteins" and "survival proteins". PLoS Genet. 2009, 5. [CrossRef] [PubMed]

16. Vesper, O.; Amitai, S.; Belitsky, M.; Byrgazov, K.; Kaberdina, A.C.; Engelberg-Kulka, H.; Moll, I. Selective translation of leaderless mRNAs by specialized ribosomes generated by MazF in Escherichia coli. Cell 2011, 147, 147-157. [CrossRef] [PubMed]

17. Chopra, N.; Saumitra; Pathak, A.; Bhatnagar, R.; Bhatnagar, S. Linkage, mobility, and selfishness in the MazF family of bacterial toxins: A snapshot of bacterial evolution. Genome Biol. Evol. 2013, 5, 2268-2284. [CrossRef] [PubMed]

18. Zhang, J.; Zhang, Y.; Zhu, L.; Suzuki, M.; Inouye, M. Interference of mRNA function by sequence-specific endoribonuclease PemK. J. Biol. Chem. 2004, 279, 20678-20684. [CrossRef] [PubMed]

19. Zhang, Y.; Zhu, L.; Zhang, J.; Inouye, M. Characterization of ChpBK, an mRNA interferase from Escherichia coli. J. Biol. Chem. 2005, 280, 26080-26088. [CrossRef] [PubMed]

20. Park, J.H.; Yamaguchi, Y.; Inouye, M. Bacillus subtilis MazF-bs (EndoA) is a UACAU-specific mRNA interferase. FEBS Lett. 2011, 585, 2526-2532. [CrossRef] [PubMed]

21. Zhu, L.; Inoue, K.; Yoshizumi, S.; Kobayashi, H.; Zhang, Y.; Ouyang, M.; Kato, F.; Sugai, M.; Inouye, M. Staphylococcus aureus MazF specifically cleaves a pentad sequence, UACAU, which is unusually abundant in the mRNA for pathogenic adhesive factor SraP. J. Bacteriol. 2009, 191, 3248-3255. [CrossRef] [PubMed]

22. Rothenbacher, F.P.; Suzuki, M.; Hurley, J.M.; Montville, T.J.; Kirn, T.J.; Ouyang, M.; Woychik, N.A. Clostridium difficile MazF toxin exhibits selective, not global, mRNA cleavage. J. Bacteriol. 2012, 194, 3464-3474. [CrossRef] [PubMed]

23. Yamaguchi, Y.; Nariya, H.; Park, J.-H.; Inouye, M. Inhibition of specific gene expressions by protein-mediated mRNA interference. Nat. Commun. 2012, 3, 607. [CrossRef] [PubMed]

24. Syed, M.A.; Koyanagi, S.; Sharma, E.; Jobin, M.C.; Yakunin, A.F.; Lévesque, C.M. The chromosomal mazEF locus of Streptococcus mutans encodes a functional type II toxin-antitoxin addiction system. J. Bacteriol. 2011, 193, 1122-1130. [CrossRef] [PubMed]

25. Miyamoto, T.; Kato, Y.; Sekiguchi, Y.; Tsuneda, S.; Noda, N. Characterization of MazF-mediated sequence-specific RNA cleavage in Pseudomonas putida using massive parallel sequencing. PLoS ONE 2016, 11, e0149494. [CrossRef] [PubMed]

26. Bukowski, M.; Lyzen, R.; Helbin, W.M.; Bonar, E.; Szalewska-Palasz, A.; Wegrzyn, G.; Dubin, G.; Dubin, A.; Wladyka, B. A regulatory role for Staphylococcus aureus toxin-antitoxin system PemIKSa. Nat. Commun. 2013, 4, 2012. [CrossRef] [PubMed]

27. Zhu, L.; Phadtare, S.; Nariya, H.; Ouyang, M.; Husson, R.N.; Inouye, M. The mRNA interferases, MazF-mt3 and MazF-mt7 from Mycobacterium tuberculosis target unique pentad sequences in single-stranded RNA. Mol. Microbiol. 2008, 69, 559-569. [CrossRef] [PubMed]

28. Zhu, L.; Zhang, Y.; Teh, J.S.; Zhang, J.; Connell, N.; Rubin, H.; Inouye, M. Characterization of mRNA interferases from Mycobacterium tuberculosis. J. Biol. Chem. 2006, 281, 18638-18643. [CrossRef] [PubMed]

29. Nariya, H.; Inouye, M. MazF, an mRNA Interferase, Mediates Programmed Cell Death during Multicellular Myxococcus Development. Cell 2008, 132, 55-66. [CrossRef] [PubMed]

30. Tripathi, A.; Dewan, P.C.; Siddique, S.A.; Varadarajan, R. MazF-induced growth inhibition and persister generation in Escherichia coli. J. Biol. Chem. 2014, 289, 4191-4205. [CrossRef] [PubMed]

31. Hazan, R.; Engelberg-Kulka, H. Escherichia coli mazEF-mediated cell death as a defense mechanism that inhibits the spread of phage P1. Mol. Genet. Genomics 2004, 272, 227-234. [CrossRef] [PubMed]

32. Alawneh, A.M.; Qi, D.; Yonesaki, T.; Otsuka, Y. An ADP-ribosyltransferase Alt of bacteriophage T4 negatively regulates the Escherichia coli MazF toxin of a toxin-antitoxin module. Mol. Microbiol. 2015, 99, 188-198. [CrossRef] [PubMed]

33. Tiwari, P.; Arora, G.; Singh, M.; Kidwai, S.; Narayan, O.P.; Singh, R. MazF ribonucleases promote Mycobacterium tuberculosis drug tolerance and virulence in guinea pigs. Nat. Commun. 2015, 6, 6059. [CrossRef] [PubMed]

34. Wang, N.R.; Hergenrother, P.J. A continuous fluorometric assay for the assessment of MazF ribonuclease activity. Anal. Biochem. 2007, 371, 173-183. [CrossRef] [PubMed] 
35. Shao, Y.; Harrison, E.M.; Bi, D.; Tai, C.; He, X.; Ou, H.Y.; Rajakumar, K.; Deng, Z. TADB: A web-based resource for Type 2 toxin-antitoxin loci in bacteria and archaea. Nucleic Acids Res. 2011, 39, 606-611. [CrossRef] [PubMed]

36. Makarova, K.S.; Wolf, Y.I.; Koonin, E.V. Comprehensive comparative-genomic analysis of type 2 toxin-antitoxin systems and related mobile stress response systems in prokaryotes. Biol. Direct 2009, 4, 19. [CrossRef] [PubMed]

37. Blower, T.R.; Short, F.L.; Rao, F.; Mizuguchi, K.; Pei, X.Y.; Fineran, P.C.; Luisi, B.F.; Salmond, G.P.C. Identification and classification of bacterial Type III toxin-antitoxin systems encoded in chromosomal and plasmid genomes. Nucleic Acids Res. 2012, 40, 6158-6173. [CrossRef] [PubMed]

38. Christensen, S.K.; Gerdes, K. RelE toxins from Bacteria and Archaea cleave mRNAs on translating ribosomes, which are rescued by tmRNA. Mol. Microbiol. 2003, 48, 1389-1400. [CrossRef] [PubMed]

39. Prysak, M.H.; Mozdzierz, C.J.; Cook, A.M.; Zhu, L.; Zhang, Y.; Inouye, M.; Woychik, N.A. Bacterial toxin YafQ is an endoribonuclease that associates with the ribosome and blocks translation elongation through sequence-specific and frame-dependent mRNA cleavage. Mol. Microbiol. 2009, 71, 1071-1087. [CrossRef] [PubMed]

40. Christensen-Dalsgaard, M.; Jørgensen, M.G.; Gerdes, K. Three new RelE-homologous mRNA interferases of Escherichia coli differentially induced by environmental stresses. Mol. Microbiol. 2010, 75, 333-348. [CrossRef] [PubMed]

41. Jørgensen, M.G.; Pandey, D.P.; Jaskolska, M.; Gerdes, K. HicA of Escherichia coli defines a novel family of translation-independent mRNA interferases in bacteria and archaea. J. Bacteriol. 2009, 191, 1191-1199. [CrossRef] [PubMed]

42. Arcus, V.L.; Mckenzie, J.L.; Robson, J.; Cook, G.M. The PIN-domain ribonucleases and the prokaryotic VapBC toxin-antitoxin array. Protein Eng. Des. Sel. 2011, 24, 33-40. [CrossRef] [PubMed]

43. Shimada, M.; Takayama, M.; Asada, K.; Kato, I. Endoribonuclease. U.S. Patent 7,989,184, 5 June 2012.

44. Schifano, J.M.; Vvedenskaya, I.O.; Knoblauch, J.G.; Ouyang, M.; Nickels, B.E.; Woychik, N.A. An RNA-seq method for defining endoribonuclease cleavage specificity identifies dual rRNA substrates for toxin MazF-mt3. Nat. Commun. 2014, 5, 3538. [CrossRef] [PubMed]

45. Wang, X.; Lord, D.M.; Hong, S.H.; Peti, W.; Benedik, M.J.; Page, R.; Wood, T.K. Type II toxin/antitoxin MqsR/MqsA controls type V toxin/antitoxin GhoT/GhoS. Environ. Microbiol. 2013, 15, 1734-1744. [CrossRef] [PubMed]

46. Sevin, E.W.; Barloy-Hubler, F. RASTA-Bacteria: A web-based tool for identifying toxin-antitoxin loci in prokaryotes. Genome Biol. 2007, 8, R155. [CrossRef] [PubMed]

47. Gerdes, K.; Christensen, S.K.; Løbner-Olesen, A. Prokaryotic toxin-antitoxin stress response loci. Nat. Rev. Microbiol. 2005, 3, 371-382. [CrossRef] [PubMed]

48. Crooks, G.; Hon, G.; Chandonia, J.; Brenner, S. WebLogo: A sequence logo generator. Genome Res. 2004, 14, 1188-1190. [CrossRef] [PubMed]

(C) 2016 by the authors; licensee MDPI, Basel, Switzerland. This article is an open access article distributed under the terms and conditions of the Creative Commons Attribution (CC-BY) license (http://creativecommons.org/licenses/by/4.0/). 